\title{
Grey Seal Predation in Cod Gillnet Fisheries in the Central Baltic Sea
}

\author{
S. Königson and S.-G. Lunneryd \\ Institute of Coastal Research, Swedish Board of Fisheries, \\ Box 4, 45321 Lysekil, Sweden \\ Email: sara.konigson@fiskeriverket.se \\ H. Stridh \\ Department of Systems Ecology, \\ Stockholm University, 10691 Stockholm \\ F. Sundqvist \\ Institute of Coastal Research, Swedish Board of Fisheries, \\ Skällåkra 411, 43024 Väröbacka, Sweden
}

Königson, S., S.-G. Lunneryd, H. Stridh, and F. Sundqvist. 2009. Grey seal predation in cod gillnet fisheries in the central Baltic Sea. J. Northw. Atl. Fish. Sci., 42: 41-47. doi: 10.2960/J.v42.m654

\begin{abstract}
The conflicts between grey seals and the cod fisheries in the Swedish Baltic Sea have increased steadily during the past 10 years. In this study we investigated damage to catches caused by seals in the inshore gillnet fishery for cod in the central Baltic Sea. Damage by seals includes both visible catch losses such as fish remains found and hidden losses where fish are removed entirely without leaving any visible fish remains in the net.
\end{abstract}

An observer joined two professional fishermen in two locations, recording the fishing effort and catches on their daily fishing trips for a period of three months each year in 2005 and 2006. To estimate the hidden losses, marked fish were manually entangled in the nets before resetting. When hauling the nets, the number of marked fish either damaged or lost was used to calculate the "hidden" losses.

A total of 324 fleets of nets were set and on 169 of these settings, damaged fish were found in the nets when hauled. 59 previously set fleets were selected for experimental trials in which fish were marked and replaced in the nets in order to estimate the extent of the hidden losses, and 39 of these set fleets were found to have been visited by seals. The mean hidden losses were calculated to be $44.2 \%$ of the marked fish (95\% C.I 33.9-54.5) after allowing for fish lost due to handling of the nets. On average 4.1 fish were lost for each fish found damaged (max. 25.6 and min. 1.6) in 2005 and in 2006 the ratio was 2.7 (max. 11.3 and min. 1.4). Extrapolating these numbers to the actual catches landed in the fishery observed, the hidden losses would correspond to $36 \%$ of the total potential catches or $67 \%$ of the landed catches in 2005 , and to $15 \%$ of the total potential catches or $19 \%$ of the landed catches in 2006.

The results from the present study show that the damage caused by grey seals such as in hidden as well as visible catch losses are significant and that this needs to be taken into account when estimating the total impact of seal predation on fisheries.

Keywords: Baltic Sea, cod, Gadus morhua, gillnets, grey seals, Halichoereus grypus, predation

\section{Introduction}

Small scale fisheries with nets and static gear are found all around the Swedish coastline and are of great importance in many coastal villages. These fisheries tend to suffer from diminishing fish stocks and structural problems. In the Baltic the cod population has declined and there has been a shift from a cod-dominated to a clupeid-dominated ecosystem in recent years (Österblom, MS 2006). Currently the prey species preferred by 
seals, such as cod, are low in number, while seal numbers are increasing. Even though the decline of the cod stocks cannot be correlated with the increase in the seal population, more likely the decline is due to over fishing (Österblom, MS 2006), it is likely that the recovery of the fish stocks will be affected by that increase. In addition to declining fish stocks and structural problems, the coastal fisheries in the Baltic Sea are also subjected to damage caused by grey seals (Halichoereus grypus). The grey seal population in the Baltic Sea has increased dramatically during recent decades (Hårding, 2007) and the seal-fisheries conflict has escalated in parallel with the population increase (Baltscheffsky, 1997; Lunneryd, 2001; Fjälling, 2005; Kauppinen et al., 2005; Westerberg et al., 2006). Fisheries using static gear in the north Baltic, where salmon (Salmo salar) and whitefish (Coregonus lavaretus) are the target species, have been considered to be the fisheries most exposed to seal damage. However in recent years, reports of seal damage in the cod fisheries of the central Baltic have increased significantly (Swedish Board of Fisheries, 2009).

The Baltic grey seal population was thought until recently to be low in numbers. In the central and southern Baltic Sea, conflicts with the cod fishery have recently appeared, but only a few hundred seals were counted in that area. Herring (Clupea harengus) is the dominant species in the diet of grey seals in the Baltic Sea. In the central Baltic Sea, cod do occur in the diet of seals, but sprat (Sprattus sprattus), whitefish, flounder (Platichthys flesus) and members of the Cyprinidae family occur more frequently than cod (Lundström et al., 2007).

The coastal fishery for cod in the central Baltic Sea is often carried out with small boats handled by one fisherman. According to the official EU logbooks, in which licensed fishermen report their daily catches and fishing effort, there were 267 boats gillnetting for cod in the Baltic Sea in 2007. The mean catch per boat was $10400 \mathrm{~kg}$. The normal gear when fishing for cod is bottom-set gillnets about $100 \mathrm{~m}$ long, linked together in rows of about seven to ten nets, creating a fleet. Several fleets, which together can be about $6000 \mathrm{~m}$ long, are often set during one fishing trip.

Seals are known to locate the nets and to damage both the fish caught and the nets. In several reports on the conflict between seals and fisheries, the percentage of damaged fish found in the catch is given as a measure of seal-induced losses (Wickens, 1995). These data only estimate a small part of the actual losses caused by seals. Besides the visible seal-induced catch losses such as damaged fish, there are likely to be other losses that are hidden from the observer. Such losses include fish that are removed completely from the fishing gear, leaving no traces. Potter and Swain (1979) estimated that seals removed $5 \%$ of the catch in salmon gillnets fishing in northeastern England. Fjälling (2005) estimated the hidden losses in salmon set-traps to be at least $20 \%$ of the total catch, and more than $50 \%$ of the potential catch for an average day with a seal visit. Königson et al. (2007) described the hidden losses in the herring fisheries in the Baltic Sea as significant. As well as taking caught fish, seals can also scare fish away from the fishing gear, potentially creating additional hidden losses (Königson et al., 2007). Consequently, catch losses could be much larger than the observed fish remains in the nets. This study aims to investigate the hidden damage by seal predation in the cod gillnet fisheries in the central Baltic Sea.

\section{Methods}

\section{Fishery data}

The field studies were conducted between April and July in 2005 and 2006 in collaboration with two local fisherman from a small fishing village on the northeast coast of Öland in the central Baltic at latitude $57^{\circ} 19^{\prime} \mathrm{N}$ (Fig. 1). An observer joined the fishermen on their daily fishing trips with gillnets aimed for cod. Records were kept of intact catches, damaged catches and fishing effort. The gillnets used in the study were $100 \mathrm{~m}$ long, 3.5 to $6 \mathrm{~m}$ in height and with mesh sizes of $55 \mathrm{~mm}$ to $65 \mathrm{~mm}$ bar length. The gillnets were made of monotwist nylon twine comprising of 4 threads each $0.123 \mathrm{~mm}$ in thickness. The nets were linked together to form $1000 \mathrm{~m}$ long fleets, and deployed 0.6 to 10 nautical miles off the coast. The mean depth where the fleets were set was $40 \mathrm{~m}$ (ranging from $10 \mathrm{~m}$ to $78 \mathrm{~m}$ ). The nets were set in the afternoon and hauled the following morning. From two to six fleets were set on each fishing trip. Systematic seal observations were carried out by the observer both during setting and hauling of the nets in order to get an estimate of the number of seals in the vicinity of the nets. The observer scanned for seals for 1 minute at a time in 2005 and 2 minutes in 2006, in each of the boat's cardinal directions, fore, aft, starboard and port, during setting and hauling of the fleets. The numbers of damaged fish per fleet were recorded, as well as the intact fish and any bycatch of birds and seals.

The catch per unit of effort, CPUE, (number of intact cod per $100 \mathrm{~m}$ net per day) and the damaged catch per unit of effort, DPUE, (number of visible damaged 


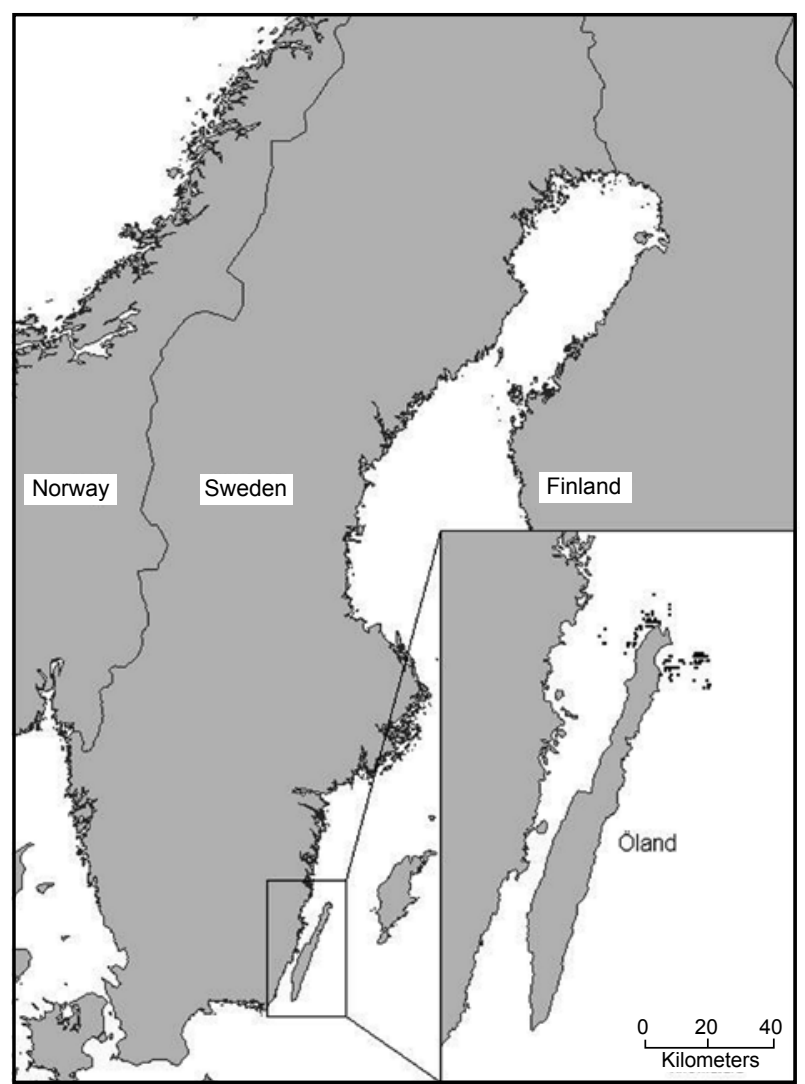

Fig. 1. The study was carried out off the north of Öland, an island situated in the central Baltic Sea. The black spots are the positions of all set fleets of nets.

fish per $100 \mathrm{~m}$ net per day) were calculated for each fleet hauled. Because catch figures were not normally distributed, a bootstrap re-sampling procedure (2 000 repetitions) using bias-corrected confidence intervals (Haddon, 2001) was used. A Visual Basic macro was used in Excel to simulate the data collection procedure with repeated re-sampling.

\section{Hidden losses}

In order to estimate the hidden losses, an experimental fleet of $1000 \mathrm{~m}$ was used. The experimental fleet was operated as follows. When hauling the fleets on a regular fishing trip, the first fleet of nets with at least five intact fish caught was selected as the experimental fleet. These first five to ten fish were left in the fleet and marked with a number. The rest of the fleets were emptied of all fish and fish remains. When less than five cod were caught in the original settings, additional cod (usually freshly caught from nets hauled on the same fishing trip, however on occasions with no other catch available, frozen fish were used) were manually entangled into the net and marked so that the experimental fleet always had at least five entangled fish as bait. To make sure that the fish were properly attached to the net, at least three meshes were snagged into the gill covers, resembling the way the cod is naturally entangled. The marking of the fish was done by attaching a piece of tape with a number to the net in close proximity to the fish. Before being marked, each fish was examined to make sure that it was fresh and without damage caused by seals. All fish used in the experimental fleet were measured. The experimental fleet baited with marked fish was reset in a new fishing location. The other regular fleets were also reset in new fishing locations. When the nets were hauled after about 29 hours, the numbers of lost and damaged marked fish were recorded.

The proportions of marked fish likely to be lost due to handling of the nets was estimated by setting a control fleet with marked fish entangled, and then hauling the fleet immediately. This was done for control fleets with both self-entangled marked fish and manually entangled marked fish.

The hidden losses were calculated for those experimental fleets which seals were judged to have visited i.e. when more than one of the marked fish was lost without a trace, or marked fish were retrieved with seal damage. The relative number of lost or damaged marked fish was calculated after correcting for the fish lost due to handling. To compare mean values, a $t$-test was used when the data was normally distributed and a Mann Whitney $U$-test when data was not normally distributed.

In order to estimate the ratio of hidden losses compared to visible losses, the mean relative number of lost marked fish was divided by the mean proportion of damaged marked fish. The total hidden losses during the entire study period at both locations were estimated by extrapolating the same ratio to the total number of damaged fish recorded in the study.

\section{Results}

\section{Fishery data}

An observer joined two fishermen at two fishing locations (northwest and northeast of Öland) for a total of 108 fishing trips over the course of two seasons (Table 1). A total of 324 fleets of nets were set during these fishing trips. Fish damaged by seals were observed on 82 of 108 fishing trips. The majority of the observed fishing trips were at the location northwest of Öland, where the 
TABLE 1. Compiled data from the fishing trips observed in 2005 and 2006.

\begin{tabular}{|c|c|c|c|c|c|c|c|}
\hline Fishing location & Year & $\begin{array}{c}\text { No. of fishing } \\
\text { occasions }\end{array}$ & $\begin{array}{c}\text { No. of } \\
\text { fleets set }\end{array}$ & $\begin{array}{c}\text { No. of cod } \\
\text { caught }\end{array}$ & $\begin{array}{c}\text { No. of } \\
\text { damaged } \\
\text { cod retrieved }\end{array}$ & $\begin{array}{c}\text { No. of fleets } \\
\text { with dam- } \\
\text { aged cod }\end{array}$ & $\begin{array}{c}\% \text { of fleets } \\
\text { with caught } \\
\text { damaged cod }\end{array}$ \\
\hline \multirow[t]{2}{*}{ Northwest of Öland } & 2005 & 32 & 93 & 1752 & 381 & 79 & 84.9 \\
\hline & 2006 & 41 & 83 & 2541 & 155 & 38 & 45.8 \\
\hline \multirow[t]{2}{*}{ Northeast of Öland } & 2005 & 21 & 91 & 915 & 54 & 22 & 24.2 \\
\hline & 2006 & 14 & 57 & 1009 & 101 & 30 & 52.6 \\
\hline Total & 2005-2006 & 108 & 324 & 6217 & 691 & 169 & 52.2 \\
\hline
\end{tabular}

seal interference was more severe than at the northeast Öland location. In the northwest area more than $80 \%$ of the fleets had fish damaged in 2005 (Table 1).

The mean CPUE (numbers of intact cod caught per $100 \mathrm{~m}$ net per day) was significantly higher in 2006 (mean 2.38, 95\% CI 1.75-3.02) compared to 2005 (mean 1.44, 95\% CI 1.16-1.72). In contrast, the mean DPUE (numbers of damaged cod per $100 \mathrm{~m}$ net per day) was significantly lower in 2006 (mean 0.12 , 95\% CI 0.08-0.16) compared to 2005 (mean 0.23 , 95\% CI 0.18-0.28). Both the mean CPUEs and DPUEs per week varied over the seasons with an increase in the early summer. The compiled data from 2005 and 2006 show a variation in CPUEs as well as DPUEs over the fishing season with the highest CPUEs and DPUEs at the end of May and beginning of June(weeks 21 to 22) ( Fig. 2).

\section{Seal observations}

During the setting and hauling of the 324 fleets, grey seals were observed near the nets only three times during the systematic observations. However, the systematic observations covered only a small part of the fishing operations and on 16 occasions one or two grey seals were observed near the nets at other times. No cormorants (Phalacrocorax carbo) or other marine mammals were observed. There was no significant difference between the CPUEs from set fleets when seals were observed and fleets set without observations of seals close to the fishing locations. Mean CPUE with seals observed was 1.51 (95\% CI 0.76-4.1), and mean CPUE without seals observed was 1.80 (95\% CI 0.6-3.0).

\section{Hidden losses}

A total of 59 experimental fleets with marked fish were set during 52 fishing trips. The majority (39) of these fleets were set northwest of Öland. A total of 425 cod were entangled and marked in the nets when resetting the nets and 164 of these were lost (Table 2).

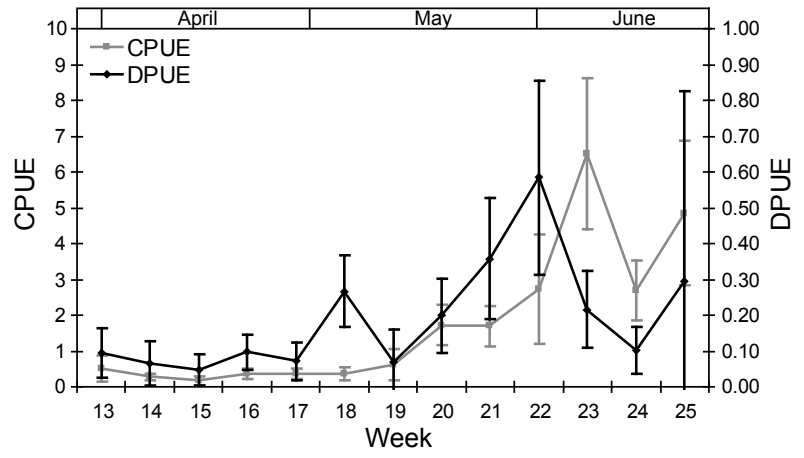

Fig. 2. Mean CPUEs (number of intact cod per $100 \mathrm{~m}$ net day) and DPUEs (number of damaged cod per 100 $\mathrm{m}$ net day) per week for both the northeast and the northwest Öland fishing locations in 2005 and 2006, combined.

Control fleets were set, using 26 fleets in which a total of 159 cod were entangled (Table 3). The numbers of fish still entangled when hauling the fleet after a short time were recorded. The mean proportion of fish that was lost due to handling the nets was $3.7 \%(95 \%$ CI 0.0-9.0) for self-entangled fresh fish, 2.6\% (95\% CI $0.0-5.2)$ for manually entangled fresh fish, and $2.8 \%$ (95\% CI 0.0-11.1) for defrozen and manually entangled fish (Table 3). The mean proportion of fish lost due to handling with no regard to the way the fish was entangled was 3.0\% (95\% CI 1.0-5.5). There was no significant difference in the mean proportion of fish lost due to handling between the three different ways of entanglement (Mann-Whitney $U$-test, $p>0.05$ ). Therefore the mean percentage of fish falling off could be used for all ways of entanglement. During all the control trials there was never more than one fish per fleet that was lost due to handling the nets. Nevertheless we assumed that on every occasion when marked fish were set out, one fish was lost by handling. The equivalent mean loss of one fish per setting for all marked entangled fish was calculated to be $15.0 \%$ (95\% CI 13.9-16.1) which was well 
TABLE 2. The locations, year, number of fleets raided by seals as indicated by marked fish remains found or marked cod lost without a trace, number of marked fish set out in the course of the fleets set with seal visits. Numbers of marked fish and damaged marked fish found are given.

\begin{tabular}{|c|c|c|c|c|c|c|}
\hline Location & Year & $\begin{array}{c}\text { No. of } \\
\text { fleets set }\end{array}$ & $\begin{array}{l}\text { No. of fleets } \\
\text { judged to be } \\
\text { raided by seals }\end{array}$ & $\begin{array}{l}\text { No. of marked cod } \\
\text { set out in fleets } \\
\text { raided by seals }\end{array}$ & $\begin{array}{l}\text { No. of marked cod } \\
\text { found damaged in } \\
\text { fleets raided by seals }\end{array}$ & $\begin{array}{l}\text { No. of marked cod } \\
\text { lost from fleets } \\
\text { raided by seals }\end{array}$ \\
\hline \multirow[t]{2}{*}{ Northwest of Öland } & 2005 & 15 & 11 & 89 & 3 & 59 \\
\hline & 2006 & 24 & 19 & 120 & 7 & 64 \\
\hline \multirow[t]{2}{*}{ Northeast of Öland } & 2005 & 13 & 5 & 44 & 10 & 31 \\
\hline & 2006 & 7 & 4 & 20 & 4 & 10 \\
\hline Total & 2005-2006 & 59 & 39 & 273 & 24 & 164 \\
\hline
\end{tabular}

TABLE 3. Results from the control fleets where losses due to handling were calculated. The mean percentages of losses with a bootstrapped $95 \%$ confidence interval (CI) are given for the different ways of entanglement.

\begin{tabular}{lcccc}
\hline $\begin{array}{l}\text { Method of } \\
\text { entanglement }\end{array}$ & $\begin{array}{c}\text { No. of control } \\
\text { trials }\end{array}$ & $\begin{array}{c}\text { No. of fish } \\
\text { marked }\end{array}$ & $\begin{array}{c}\text { No. of fish } \\
\text { lost }\end{array}$ & $\begin{array}{c}\text { \% of set out entangled fish } \\
\text { lost (95\% CI min.-max.) }\end{array}$ \\
\hline Self entangled & 10 & 72 & 3 & $3.7(1.0-9.0)$ \\
Manually entangled & 10 & 51 & 2 & $2.6(0.0-5.2)$ \\
Defrozen and manually entangled & 6 & 36 & 1 & $2.8(0.0-11.1)$ \\
Total & 26 & 159 & 6 & $3.0(1.0-5.5)$ \\
\hline
\end{tabular}

above the calculated maximum handling losses based on the results from the control trials. The maximum number of fish lost due to handling i.e. one fish per setting (15\%) was used as a criterion to determine whether a seal visit had taken place or not.

Thirty-nine out of the 59 experimental fleets set were raided by seals. In fleets subjected to seal damage, a total of $44.2 \%$ (95\% C.I 33.9-54.5) of the marked cod was lost, after correcting for fish lost due to handling. A total of $13.5 \%$ of the marked fish was damaged (visible losses). There was no significant difference in hidden or visible losses between the two fishing locations during the two fishing seasons. The hidden losses were larger in $2005(57 \%)$ than in $2006(35 \%)(t$-test, $p<0.005)$. There were however no significant differences in the visible losses between 2005 and 2006 ( Fig. 3).

There was no significant difference in the CPUEs between fleets visited by seals (with lost or damaged marked fish) and fleets not visited by seals. Fleets visited by seals had a CPUE of 2.57 (95\% CI 1.71-3.63) compared to fleets with no seal visit with 3.41 (95\% CI 2.22-4.69).
Because of the difference in hidden losses in 2005 and 2006 as well as that there was no difference in visible losses in 2005 and 2006, the ratios of hidden losses to visible losses were different over the two fishing seasons. In 2005, an average of 4.1 fish were estimated lost per one damaged fish found (min. 1.6 and max. 25.6), while the ratio of fish lost to fish damaged was only 2.7 (min. 1.4 and max. 11.3) in 2006. In 2005, 435 cod were found damaged and 2667 were found intact in 53 fishing trips. When using the ratio of fish lost to fish damaged (4.1), hidden losses was extrapolated to be $1774 \mathrm{cod}$ (680-11 127) in 2005, which correspond to $36.4 \%$ of the total potential catch and to $66.5 \%$ of the retrieved intact catch. The total damage by grey seals, including both visible and hidden losses, represents $45.3 \%$ of the total potential catch and as much as $82.8 \%$ of the retrieved intact catch. In the observed fishery in 2006, $256 \mathrm{cod}$ were found damaged while the intact catch was 3550 cod (during 55 trips). The hidden losses were estimated to be $683 \operatorname{cod}(351-2882)$ in 2006. This figure amounts to $15.2 \%$ of the total potential catch and $19.2 \%$ of the retrieved intact catch. Both visible and hidden losses together would make up $20.9 \%$ of the total potential catch and $26.5 \%$ of the retrieved intact catch. 


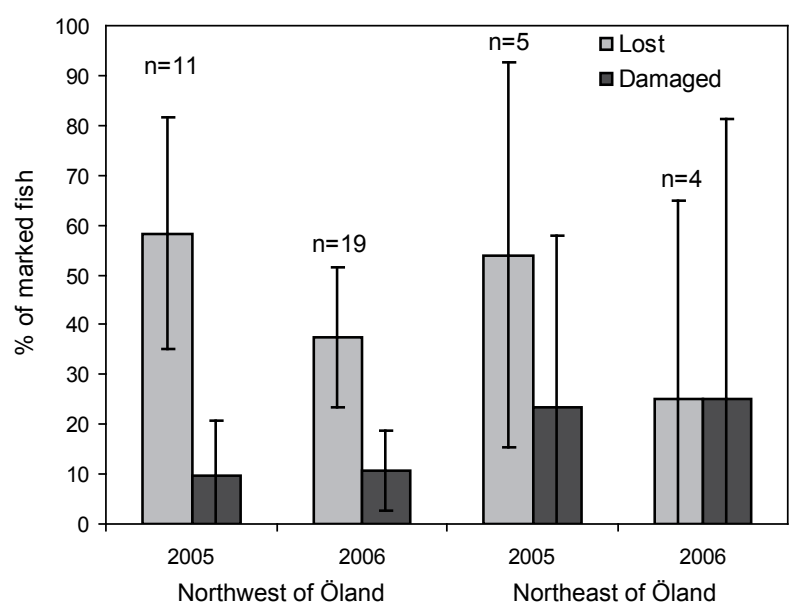

Fig. 3. The percentage of marked fish lost or damaged. The number of fish lost gives the estimated hidden losses after correcting for losses due to net handling.

\section{Discussion}

The results in this study show that the amount of visible damage by grey seals in the cod fishery in the study area is significant. In more than $50 \%$ of the fleets set or $76 \%$ of the fishing trips, fish damaged by seals were found. The visible damaged catch per unit effort (DPUE) and the entire intact catch per unit effort (CPUE) both varied during the fishing season. The CPUE and the DPUE increased in the beginning of May. The peak season for the cod fishery in the study area is in the beginning of June, which is the time when the cod starts to spawn. The reason for the DPUE increasing along with the CPUE could be because the number of seals raiding the nets increases when there are more fish caught in the net and easily accessible. Another reason for the increased seal damage could be that seals take bites out of several fish when there are more fish available, rather than eating the entire fish. A hungry seal might eat a whole cod, but a partly satisfied seal might only take parts of a fish and leave a large part behind. A decrease in seal damage might be expected in late May and June because this is the peak season for grey seals to haul-out during their annual moult in these areas (Hårding, 2007). However, this idea is not supported by the results in this study or by reports on seal interactions in the EU logbooks. To sum up, the visible damage by seals in fact occurs throughout the entire fishing season and constitutes a large part of the catch.

However, this is far from the whole story. The total catch losses due to seals include both visible and hidden losses. A large proportion of the marked cod in this study was lost from the pre-baited fleets of nets, i.e. constitut- ed losses which would normally be hidden. The hidden losses were estimated to be as high as $36 \%$ of the total potential catch in 2005 and $15 \%$ in 2006 and $67 \%$ of the retrieved intact catch in 2005 and $19 \%$ of the retrieved catch in 2006. There was no significant difference in hidden losses in the two study areas. High additional catches on the experimental fleets could affect the amount of hidden losses and be the reason for the difference in hidden losses over the years. If the marked fish are only a small proportion of the total fish catch in the fleet, then the seal has more fish to choose and it is likely that the seal will take unmarked fish instead of marked fish. The CPUE was higher in 2006 than in 2005 however the DPUE was more severe in 2005 than in 2006. However an important factor is the proportion of hidden losses relative to visible losses. This will give us a more accurate estimation of the true loss of catch due to seals. The results from this study show that the hidden losses are likely to be much greater than the visible losses. For every damaged fish found, there are about four fish lost, due to seals.

Possible sources of bias in our experimental set-up were considered. The fish caught and marked are already dead when the experimental fleet is reset. They might therefore be less easily visible to seals than a live cod caught and wriggling in the net. Shulte-Pelkum et al. (2007) investigated the ability of seals to follow a hydrodynamic trail and concluded that the movement of fish in the water are used by seals to detect their prey. This factor would lead to hidden losses being under-estimated. Again, seals might prefer to eat fresh fish to dead fish and therefore not take the marked fish in the nets. However, studies have indicated that seals are not fastidious and will in fact eat several days dead fish (Lunneryd, 2001; Königson et al., 2007).

Results from the control nets set to study the loss of marked cod due to handling showed that the fall-off due to handling was low (mean 3.0\% loss of entangled fish set out with a CI 95\% CI 1.03-5.5). Nevertheless the hidden loss factor was calculated under the assumption that one fish fell off each net during handling, which overestimates handling losses and therefore leads to an underestimate of seal-induced losses. One factor which might overestimate the hidden loss is the longer exposure time of the marked fish in the experimental fleet compared to fish caught on the same net, because the marked fish have been available to the seals for a longer time period.

Any estimation of hidden seal-induced losses should ideally also take account of fish that might be scared away from the fishing gear, and thereby not caught in the nets, due to the presence of seals. Königson et al. 
(2007) concluded that the presence of seals can indeed scare away schools of herring from nearby fishing gear. However, in the present study we did not observe a significant decrease in CPUEs on the experimental fleets subjected to seal visits compared to fleets with no seal visit. An additional direct cost due to seal interference is damage to the fishing net, which was impossible to quantify in the present study. Net damage can range from ripping a single strand of mesh up to one metre long tears. There is a general complaint from fishermen that they have to replace their fishing gear more frequently when seal interference escalates. To sum up, the present study shows that the impact of grey seals on the cod gillnet fishery is negative and serious. Seals represent a larger threat to the cod fishery in the Baltic than is commonly appreciated. Catch losses, visible and hidden, caused by seals in the cod fisheries could therefore be taken into consideration in the management plans for cod as well as for grey seal.

\section{Acknowledgements}

We are most grateful to Magnus and Karl Sandin as well as Tore Johnsson, who taught us everything there is to know about cod fishing and supported us in our work by letting us come along on their fishing trips. Good cooperation between fishermen and researchers are crucial when studying fisheries. This study was financed by the Programme Seal and Fishery, Swedish Environmental Protection Agency and the Swedish Board of Fisheries.

\section{References}

BALTSCHEFFSKY, S. 1997. Seals in the Bothnian Sea: From endangered species to coastal nuisance. Enviro, 23: 9.

FJÄLLING, A. 2005. The estimation of hidden seal-inflicted losses in the Baltic Sea set-trap salmon fisheries. ICES J. Mar. Sci., 62:1630-1635. doi:10.1016/j. icesjms.2005.02.015

HADDON, M. 2001. Modelling and quantitative methods in fisheries. Chapman \& Hall/CRC., 406 p.
HÅRDING, K., T. HÄRKÖNEN, B. HELANDER, and O. KARLSSON. 2007. Status of Baltic grey seals: Population assessment and extinction risk. NAMMCO Sci. Publ., 6: $33-56$.

KAUPPINEN, T., A. SIIRA, and P. SUURONEN. 2005. Temporal and regional patterns in seal-induced catch and gear damage in the coastal trap-net fishery in the northern Baltic Sea: effect of netting material on damage. Fish. Res., 73: 99-109. doi:10.1016/j.fishres.2005.01.003

KÖNIGSON, S., A. FJÄLLING, and S. G. LUNNERYD. 2007. Grey seal induced catch losses in the herring gillnet fisheries in the northern Baltic. NAMMCO Sci. Publ., 6: 203-213.

LUNDSTRÖM, K., O. HJERNE, K. ALEXANDERSSON, and O. KARLSSON. 2007. Estimation of grey seal (Halichoerus grypus) diet composition in the Baltic Sea. NAMMCO Sci. Publ., 6: 177-196.

LUNNERYD, S. G. 2001. Fish preference by harbour seal (Phoca vitulina), with implications for the control of damage to fishing gear. ICES J. Mar. Sci., 58(4): 824-829. doi:10.1006/jmsc.2001.1073

ÖSTERBLOM, H. MS 2006. Complexity and change in a simple foodweb -Studies in the Baltic Sea (FAO Area 27.111.d). Ph. D. thesis, Stockholm University, Sweden.

POTTER, E. C. E., and A. SWAIN. MS 1979. Seal predation in the North East England coastal salmon fishery. ICES CM 1979/N: 9-4, 4 p.

SCHULTE-PELKUM, N., S. WIESKOTTEN, W. HANKE, G. DEHNHARDT, and B. MAUCK. 2007. Tracking of biogenic hydrodynamic trails in harbour seals (Phoca vitulina). J. Exp. Biol., 210: 781-787. doi:10.1242/jeb.02708

SWEDISH BOARD OF FISHERIES. 2009. Fish stocks and environment in marine and inland waters. Swedish Assessments 2009, 29 p. https://www.fiskeriverket.se/downl oad/18.7e2791921225aba85fa80001361/RoM_eng_web. pdf

WESTERBERG, H., S. G. LUNNERYD, S. G. A. FJÄLLING, and M. WAHLBERG. 2007. Reconciling fisheries activities with the conservation of seals through the development of new fishing gear: a case study from the Baltic fishery - grey seal conflict. Reconciling fisheries with Conservation: Proceedings of the Fourth World Fisheries Congress. Am. Fish. Soc. Symp., 49: 587-598.

WICKENS, P. 1995. A review of operational interactions between pinnipeds and fisheries. FAO Fish. Tech. Pap., No. $346,86 \mathrm{p}$. 